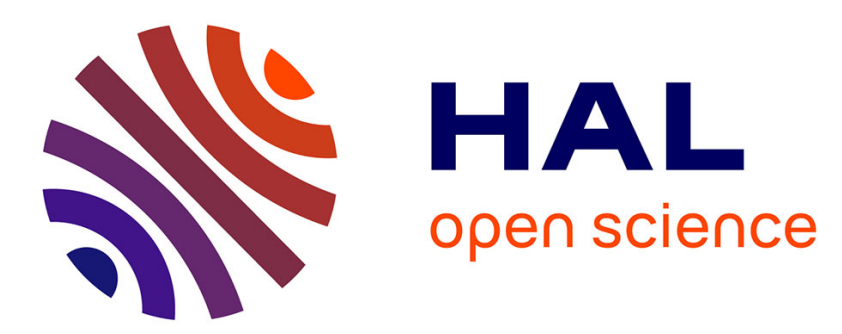

\title{
Size, Innovation and Internationalization: A Survival Analysis of Italian Firms
}

Giorgia Giovannetti, Giorgio Ricchiuti, Margherita Velucchi

\section{To cite this version:}

Giorgia Giovannetti, Giorgio Ricchiuti, Margherita Velucchi. Size, Innovation and Internationalization: A Survival Analysis of Italian Firms. Applied Economics, 2009, pp.1. 10.1080/00036840802600566 . hal-00582293

\section{HAL Id: hal-00582293 \\ https://hal.science/hal-00582293}

Submitted on 1 Apr 2011

HAL is a multi-disciplinary open access archive for the deposit and dissemination of scientific research documents, whether they are published or not. The documents may come from teaching and research institutions in France or abroad, or from public or private research centers.
L'archive ouverte pluridisciplinaire HAL, est destinée au dépôt et à la diffusion de documents scientifiques de niveau recherche, publiés ou non, émanant des établissements d'enseignement et de recherche français ou étrangers, des laboratoires publics ou privés. 


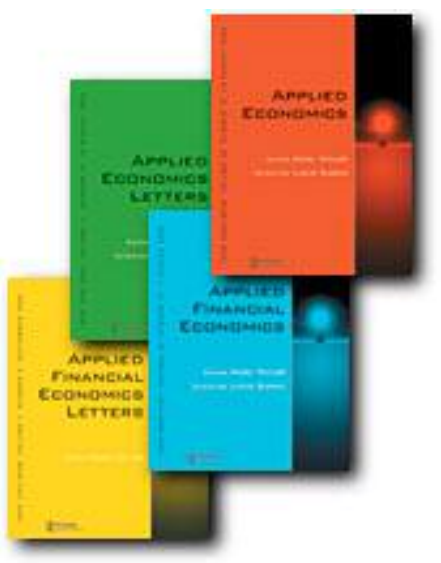

Size, Innovation and Internationalization:

A Survival Analysis of Italian Firms

\begin{tabular}{|c|c|}
\hline Journal: & Applied Economics \\
\hline Manuscript ID: & APE-08-0028.R1 \\
\hline Journal Selection: & Applied Economics \\
\hline $\begin{array}{r}\text { Date Submitted by the } \\
\text { Author: }\end{array}$ & 02-Jul-2008 \\
\hline Complete List of Authors: & $\begin{array}{l}\text { Giovannetti, Giorgia; Fondazione M. Masi; Univerisità degli Studi di } \\
\text { Firenze, Dipartimento Scienze Economiche } \\
\text { Ricchiuti, Giorgio; Università degli Studi di Firenze, Dipartimento } \\
\text { Scienze Economiche } \\
\text { Velucchi, Margherita; Università degli Studi di Firenze, Dipartimento } \\
\text { di Statistica "G. Parenti" }\end{array}$ \\
\hline JEL Code: & $\begin{array}{l}\text { C41 - Duration Analysis < C4 - Econometric and Statistical } \\
\text { Methods: Special Topics < C - Mathematical and Quantitative } \\
\text { Methods, L11 - Production, Pricing, and Market Structure|Size } \\
\text { Distribution of Firms < L1 - Market Structure, Firm Strategy, and } \\
\text { Market Performance < L - Industrial Organization, L25 - Firm Size } \\
\text { and Performance < L2 - Firm Objectives, Organization, and } \\
\text { Behavior < L - Industrial Organization, F21 - International } \\
\text { Investment|Long-Term Capital Movements < F2 - International } \\
\text { Factor Movements and International Business < F - International } \\
\text { Economics }\end{array}$ \\
\hline Keywords: & $\begin{array}{l}\text { Business Demography , Competitiveness, Internationalization, } \\
\text { Survival Analysis }\end{array}$ \\
\hline
\end{tabular}




\section{S) ScholaronE \\ Manuscript Central}

Editorial Office, Dept of Economics, Warwick University, Coventry CV4 7AL, UK 


\title{
Size, Innovation and Internationalization: \\ A Survival Analysis of Italian Firms ${ }^{1}$
}

\author{
Giorgia Giovannetti \\ Dipartimento Scienze Economiche, Università degli Studi di Firenze and Fondazione Masi \\ via delle Pandette 9, 50127 Firenze \\ Giorgio Ricchiuti \\ Dipartimento Scienze Economiche, Università degli Studi di Firenze, via delle Pandette 9, 50127 \\ Firenze \\ Margherita Velucchi \\ Dipartimento di Statistica "G. Parenti", Università degli Studi di Firenze, viale G.B. Morgagni 59, \\ 50134 Firenze
}

\begin{abstract}
Firms' survival is often seen as crucial for economic growth and competitiveness. This paper focuses on business demography of Italian firms, using an original database, obtained by matching and merging to gain the intersection three firm level datasets. This database allows us to simultaneously consider the effect of size, technology, trade, foreign direct investments, and innovation on firms' survival probability. We show that size and technological level positively affect the likelihood of survival. Internationalized firms show higher failure risk: on average competition is stronger in international markets, forcing firms to be more efficient. However, large internationalized firms are more likely to 'survive'. An Italian internationalized firm to be successful and to survive, should be high-tech, large and innovative.
\end{abstract}

Keywords: Business Demography, Survival, Competitiveness, Internationalization

JEL: C41, L11, L25, F21

1 Corresponding author: Giorgio Ricchiuti, Dipartimento Scienze Economiche, Facoltà di Economia, Università degli Studi di Firenze, via delle Pandette 9, 50127, Firenze (Italy), giorgio.ricchiuti@unifi.it. 


\section{Introduction}

Several years ago, the Lisbon European Council (2000) set the tenyear goal of making the European Union "the most dynamic, competitive, sustainable knowledge-based economy in the world, enjoying full employment and economic and social cohesion". Priority actions were designed to encourage an entrepreneurial culture, create additional jobs, promote high technology and knowledge-intensive sectors of the economy, and stimulate internationalization both through exports and foreign direct investment (FDI). These goals are still far from being achieved, especially in Italy, which seems to lag behind other EU countries in terms of the Lisbon targets, therefore representing an interesting case to focus on.

Data from ISTAT (2005) and Eurostat (2006) highlight that $22 \%$ of the EU25 firms are Italian but their weight in terms of employment is only $11 \%$. The size of Italian firms is half the European average and their productivity is $10 \%$ lower. Italian firms specialize in traditional low tech sectors characterized, in general, by lower productivity. Their specialization is, therefore, far from being the knowledge-intensive kind promoted by the European Council. Moreover, the international demand for traditional goods such as those produced in Italy is low and grows less than the average demand for manufacturing. These characteristics help explain the incredibly high turnover of Italian firms: 4 years after birth, only $60 \%$ of Italian firms survive, and the figure is even less for those that operate in international markets. 
A recent and increasing literature has pointed out the importance of firms' survival, as well as turnover, entry of new firms, start up, incubators etc. for growth and competitiveness of a country (see for instance Bartelsman et al., 2003, Bartelsman et al. 2004). A different strand of literature emphasizes that firms involved in international activities through export or FDI are "different" from purely domestic firms in several respect, productivity, wages, skill intensity (see for all Mayer and Ottaviano, 2008). In this paper we draw on these two so far unrelated strands of the literature and assess the relationships among firms' characteristics and their competitiveness by analyzing demographic dynamics and survival of Italian firms. More specifically, we show how the probability of survival is related to firms' size, innovation and technological level (in line with Agarwal e Audretsch, 2001) but also to firms' presence in foreign markets, both as exporters and foreign direct investors (in line with Mayer and Ottaviano, 2008).

We rely on an innovative dataset obtained by matching and merging three different firm level databases for Italy which allows us to analyze the effect of exports, FDI, innovation, size, technological level and R\&D expenditures on the firms' probability of survival for the period 20012005 in Italy. We find that size and technological level reduce the risk of failure (exit). Furthermore, the positive impact of technology increases with size: large firms that operate in high-tech sectors, on average, have a higher probability of survival than small firms in traditional sectors. Internationalized firms, on the other hand, show higher failure risk since, in general, competition in international 
markets is stronger. Our results also show that, for innovative firms, the failure risk is reduced if they operate in high-tech sectors, while non-innovative firms can survive longer if they are large enough to exploit their market power. Hence, in Italy, a successful and long-lived internationalized firm should be high-tech, large and innovative. After a brief overview of two strand of the literature (Gibrat's Law and business demography on the one and internationalization on the other hand), we sketch the econometric techniques used (Section 3) and then we present, in Section 4, our results. Section 5 concludes.

\section{From Gibrat's Law to firms' demography:}

\section{domestic versus "international" firms}

Back in 1931, Robert Gibrat proposed an explanation for skew size distributions in a number of different environments, ranging from biology to astronomy. In particular, describing manufacturing industries, he showed that the firms' size distribution is well approximated by a Log Normal: "the probability of a given proportionate change in size during a specified period is the same for all firms in a given industry - regardless of their size at the beginning of the period" (Mansfield, 1962, p. 1031). This regularity is known as the Law of Proportionate Effect or Gibrat's Law.

Until the 1970 s this Law was popular, not only because it was coherent with dynamic patterns of manufacturing firms in different countries but 
also because of its compatibility with different theoretical models. However, empirical testing soon became controversial, while theoretical models started developing different lines of research (cf. Santarelli et al, 2006), the most promising of which emphasized the existence of a strong relationship between the likelihood of survival and firm size. "Because small firms have a lower likelihood of survival than their larger counterparts, and the likelihood of small firms' survival is directly related to growth, firms' size is found to be negatively related to growth, thereby refuting Gibrat's Law" (Agarwal and Audretsch, 2001, pp 22). Hence, the greater is the "entry size" in a given industry, the higher the likelihood of survival of new entrants. On average, therefore, smaller firms have a lower probability of survival; however those who survive grow proportionately faster than larger firms (Jovanovic, 1982; Evans, 1987; Hall, 1987, Agarwal and Audretsch, 2001). Furthermore, "entry appears to be relatively easy, but survival is not" (Geroski, 1995), so that turnover can be high, especially in highly competitive markets.

A vast number of recent empirical studies, covering different time periods and countries, ${ }^{3}$ finds that size increases the likelihood of survival in the more technological advanced industries, but not in traditional sectors. Most of these studies are consistent with theories of industry evolution (Agarwal and Gort, 1996, Agarwal, 1998, Audretsch,

\footnotetext{
2 See the influential surveys by Geroski, 1995, Sutton, 1997 , Caves, 1998 and the paper by Holmes et al., 2008.

3 See, for instance, Dunne, Roberts and Samuelson, 1988, 1989 (US); Audretsch, 1991, 1995 (US); Agarwal, 1997 (US); Mata, Portugal, 1994 (Portugal); Agarwal and Audretsch, 2001 (US); Eurostat, 2006 (EU); Bartelsman et al., 2003 (OECD); Bartelsman et al., 2004 (EU and Americas). There are several applications to the service sector pointing to the positive effect of size and diversification (see Santarelli, 1998 and Leong et al., 2003).
} 
1995) and with the theory of strategic niches (Caves and Porter, 1977; Porter, 1979). According to the latter, firms remain small because they occupy product niches that are not easily accessible or profitable for their larger counterparts. A different strand of the literature has emphasized firms' heterogeneity and focused on the existence of substantial differences between domestic and internationalized firms. The underlying idea is that there are relatively few firms 'fit' to cope with the more competitive international markets and these firms are more productive, pay higher wages, employ more skilled workers, invest more in R\&D. ${ }^{4}$ In a seminal paper, Melitz (2003) maintains that firms with different level of international involvement, which are randomly allocated a productivity level, are clearly ranked: exporters are more productive than domestic firms, foreign investors more productive than exporters and so on. Our purpose is to link the literature on survival with that on mode of internationalization. To the best of our knowledge there are few studies, if any, that look simultaneously at the role of size, technology and internationalization on firms' survival rates. As will be emphasized below, some of our results are in line with the theoretical findings of the recent literature on internationalization (see Mayer and Ottaviano, 2007).

\footnotetext{
4 More precisely, this literature can be split in two: on the one side the seminal paper by Melitz, 2003 and the papers surveyed in Meyer and Ottaviano, 2008, which focus on the ranking and on the different productivity levels of firms with different international involvement. On the other hand, a large literature on learning by exporting, pioneered by Clerides, Lach and Tybout, 1998. Only some of our results, as will be emphasized below, are in line with the theoretical findings.
} 


\section{The Econometric Techniques}

To analyze whether the likelihood of survival is invariant to firm size, international involvement and to technological intensity we use the Analysis of Duration (Lancaster, 1990) that allows us to estimate the length of the time until failure. ${ }^{5}$ The variable of interest in the analysis of survival is the length of time that elapses from the beginning of some events either until "their" end or until the end of the analysis. Observations will typically consist of a cross section of durations $t_{1}, t_{2}, \ldots, t_{n} \in T$, where $T$ is a random variable (discrete or continuous), and for this type of data the analysis of duration allows one to estimate the probability that the event "failure" occurs next period. In this paper the dependent variable is the span of survival and is calculated as the difference between time $t$ and the firm's set up year while the "failure" event includes winding-up, failure or end of activity (Agarwal and Audretsch, 2001). The process observed may have started at different points in time and, because its length is not constant over time, the random variable $T$ is unavoidably censored.

Let $T$ be a random variable with a cumulative probability

$$
F(t)=\int_{0}^{t} f(s) d s=\operatorname{Pr}(T \leq t)
$$

where $f(t)$ is the continuous probability distribution. We are interested in the probability that the period is of length at least $t$, which is given by the survival function

$S(t)=1-F(t)=\operatorname{Pr}(T \geq t)$

\footnotetext{
${ }^{5}$ Simple examples are the length of a strike, the durability of electric and electronic components, the length of survival after the diagnosis of a disease or after an operation and time until business failure.
} 
and the probability that the phenomenon will end the next short interval of time, $\Delta$, is

$$
l(t, \Delta)=\operatorname{Pr}(t \leq T \leq t+\Delta \mid T \geq t)
$$

The Hazard Rate, i.e. the rate at which spells are completed after duration $t$, given that they last at least until $t$, is:

$$
\lambda(t)=\lim _{\Delta \rightarrow 0} \frac{\operatorname{Pr}(t \leq T \leq t+\Delta \mid T \geq t)}{\Delta}=\lim _{\Delta \rightarrow 0} \frac{F(t+\Delta)-F(t)}{\Delta S(t)}=\frac{f(t)}{S(t)}
$$

To measure the effect of different regressors (in our case entry size and technological level) on the survival probability of the phenomenon, we estimate the parameter $\lambda$ using Maximum Likelihood by the Cox Proportional Hazard Regressions.

The hazard function $h_{i}(t)$ of a firm $i$ is expressed as:

$h_{i}(t)=h\left(t, x_{i}\right)=h_{0}(t) \exp \left(x_{i}^{\prime} \beta\right)$

$h_{0}(t)$ being an arbitrary and unspecified baseline hazard function representing the probability of failure conditional on the fact that the firm has survived until time $t, x_{i}$ is a vector of measured explanatory variables for the $i$-th firm and $\beta$ is the vector of unknown parameters to be estimated. Negative coefficients or risk ratios less than one imply that the hazard rate decreases and the corresponding probability of survival increases.

Life-table analysis, estimating the survival rate at time $s$, where $s$ is defined as the fraction of the total number of firms that survived at least $t$ years, can also be used to show firms survival and failure rates. Life tables give the number of firms that die conditional on their age, i.e. they represent the probability of failure given that the firm has survived $t$ years. To check for significance of differences between 
groups, tests of homogeneity are usually run (in the following we use the nonparametric Log-Rank, Wilcoxon, Tarone-West and Peto-PetoPrentice tests). At each failure time $t$, the test statistics is obtained as a weighted standardized sum of the difference between the observed and expected number of exit in each of the k-groups. The null hypothesis is no difference between the survival functions of the kgroups. The weights functions used determine the test statistics (see Klein and Moeschenberger, 2003).

\section{Data and Results}

We match and merge to gain the intersection of three different datasets: Capitalia, ICE-Reprint and AIDA. ${ }^{6}$ AIDA provides standard data on budgets of Italian companies, Capitalia's Observatory on Small and Medium Size Firms is a survey on a representative sample of over 4000 Italian firms, providing information on $R \& D$, innovation, destination markets for exports etc. The sample includes all firms with more than 500 employees and firms with less than 500 employees selected using a stratified design on location, industrial activity and size. Finally, the ICEReprint database is the census of foreign affiliates of Italian firms and provides information on number of employees and sales (for details, see Mariotti and Mutinelli, 2005). In this paper, we use ICE-Reprint for information on foreign direct investment. Hence, our consolidated

6 Capitalia (9th survey, 2005) has data for the period 2001-2003, ICE-Reprint provides information for the period 2001-2003. See De Benedictis and Giovannetti (2008) for further information on the dataset and for the main characteristics of ICE-Reprint database. AIDA provides the budget and entrepreneurs' data for the period 2001-2005. See below for the exact source of each variable. 
dataset provides information on firms' processes of internationalization, economic performance, innovative capacity and growth for 4289 manufacturing firms.

The independent variable (span of survival) is calculated as:

$S_{t}=A_{t}-A_{0}+1$

where $A_{t}$ is the year corresponding to the balance sheet at year $\mathrm{t}$ and $A_{0}$ is the firms' birth year. $S_{t}$ is a censored variable because the exit from the market can happen during or before 2005 due to winding-up, failure or end of activity. In the survival analysis, $S_{t}$ represents the "failure" variable on which the exit probability is worked out. Hence, we can avoid biased estimates by distinguishing firms that failed during 2005 from those still alive in 2005 that are no longer included in the dataset as a result of falling outside the sample frame.

The technological dummy is built on the Pavitt taxonomy. It is equal zero when the firm works in traditional or in scale sectors and one otherwise. $^{7}$

Size is generated from firm's total sales. Because of the high skewness of the Italian firms' distribution, we use 5 equally represented classes, following the procedure introduced by Geweke, Marshall and Zarkin (1986), to avoid inconsistency problems in the axioms at the basis of the discrete Markov Chains theory (Fractile Markov Chains). Hence, we do not use equally sized classes but we define a number of classes $n$

7 The Pavitt taxonomy distinguishes between traditional, scale, specialized and high-tech sectors. Since in the scale sectors there are some firms that cannot be classified as "low tech", we also run the models using (1) a dummy equal to 0 only for traditional sectors and 1 otherwise and (2) the 4 Pavitt classes separately. Results are robust and available upon request. 
such that the proportion of the population ${ }^{8}$ (asset size of the firms) in each class $j$, for each $t$, is constant and equal to $n^{-1}$. This allows us to avoid classifying most firms as "small".

We use a specific question of the Capitalia survey to define the dummy variable capturing innovative capacity. The dummy is equal one if in the period 2001-2003 the firm has introduced into the market an innovative product or it has set up either a new production process or an innovation in labor organization. Finally, dichotomous variables are also defined on whether firms export, invest abroad and/or invest in $R \& D$ activities. Innovation, exports, R\&D, technology and FDI variables are drawn from the Capitalia and ICE-Reprint databases. Table 1 reports summary statistics on the whole sample. We show that $74.6 \%$ of our sample firms export, while only $10.5 \%$ invest abroad. Moreover, in the period $2001-2003,62 \%$ of firms reported at least one innovation, ${ }^{9}$ while only $44 \%$ of them spent on $R \& D^{10}$. The sample average firms' age is 24.78 years, which is quite high if compared to the average age of the Italian firms. However, the sample standard deviation is very high ${ }^{11}$.

\section{Table 1 around here}

Table 2 presents the estimation results for the entire sample $\mathrm{s}^{12}$ and some sub-samples selected by splitting the sample to single out small (class 1) and medium-large (classes 2-5), exporters and non-exporters, and innovative and non-innovative firms. Table 3 reports the homogeneity

\footnotetext{
$8 \forall \mathrm{t}$ and $\forall \mathrm{j}: 1,2, \ldots, \mathrm{n}, \pi_{\mathrm{j}, \mathrm{t}}=\mathrm{n}^{-1}, \mathrm{t}$ is time, $\mathrm{j}$ are the $\mathrm{n}$ classes and $\pi_{\mathrm{j}, \mathrm{t}}$ in class $\mathrm{j}$ at time $\mathrm{t}$. 9 Because of lack of data, we cannot distinguish between product, process and organizational innovations. 10 Life Tables analysis confirm our results; it is not reported for reasons of space but is available on request.

11 Further analysis shows that eliminating the outliers does not alter the sample average firms' age. For instance, sample including firms less than 50 years old, have an average age of 22 .

12 We also run the regressions including only size (not reported), size and technology (cf. Table 2) and size, technology R\&D and innovation. The coefficients of those variables are stable but the explanatory power in our preferred regression, which includes even internationalization variables, is higher.
} 
tests (Log-Rank, Wilcoxon, Peto-Peto Prentice and Tarone Ware) for sub groups.

\section{Table 2 around here}

\section{Table 3 around here}

Size is always statistically significant and has a positive effect in increasing survival probability. It means that, independently of the main characteristics of the economic system, larger firms have a higher probability to survive. However, its magnitude is different among the various specifications.

Considering the whole sample, all variables except innovation are significant. Larger size and higher tech increase the survival probability, while internationalizing (either by exporting or FDI) has the opposite effect: competition in international markets is harder and increases the risk of failure (more specifically, to export increases the risk of failure by $32 \%$ and to invest abroad by $38 \%)^{13}$. In Figure 1 we report the smooth hazard function for the whole sample; as can be seen, the risk of failure is relatively low (on average around $0.2 \%$ ) but keeps increasing until almost 30 years after birth and, after a short period of reduction (around ten years), starts increasing again.

\section{Figure 1 around here}

It is worth noting that size plays a more important role for exporting that for non-exporting firms. Moreover, size reduces by $20 \%$ the failure

\footnotetext{
${ }^{13}$ This result is in line with the theoretical model of Melitz and Ottaviano, 2008.
} 
risk for innovative firms but by $22 \%$ for non-innovative firms. Producing in high-tech sectors reduces the risk of failure. Particularly, firms that export high-tech goods are less vulnerable and their probability of survival increases by roughly $33 \%$. It seems that the best strategy for exporters is to operate in high-tech sectors and, secondly, to become larger.

If we split small from medium and large firms, we notice that for the former technology has a weakly (significant) effect, while for the latter a huge $(-30 \%)$ impact on failure risk. This result seems to support, somehow, the theory of strategic niches: some firms remain small because they have a comparative advantage due to the peculiar nature of the goods they produce (mainly low tech), advantage that can disappear if/when the size increases. Finally, in the sample considered, the innovative firms have higher survival probability $(+42.2 \%)$. On the contrary, for non-innovative firms operating in traditional sectors, the technological level of the goods produced does not have any effect on the failure risk. Figures 2 to 6 report sub-sample smoothed hazard functions.

\section{Figures 2 to 6 around here}

In summary, we can say that exporting and innovative activity are (on average) more risky if the firm is small and produces traditional goods. On the other hand, size plays a crucial role for those firms operating only in Italy and for non-innovative firms; in these cases, technology does not have significant effects on survival probability. 


\section{Conclusions}

Our empirical analysis suggests that, for Italian firms: 1) size and technological level reduce failure risk: the larger the firm, the greater the positive effect of technology on survival probability; 2) being an exporter or investing abroad reduces the survival probability of a firm: on average, the exposure to the strong competition in international markets increases the firms' risk of failure. Moreover, competitive firms in international markets tend to be bigger and in high-tech sectors. 3) Comparing exporting and non-exporting firms, size and technology have a stronger impact on the former than on the latter. Similarly, for innovative firms it is crucial to operate in high-tech sectors, while noninnovative firms can survive longer exploiting the market power (proxied by size).

Hence, we can claim that, in Italy in the last few years a long-lived successful firm is big and innovative, operates in high-tech sectors, and is a key player on international markets. This has a clear implication for economic policy and makes it essential to fulfil the Lisbon goals.

\section{Acknowledgement}

We would like to thank Sergio De Nardis, Fabrizio Onida, Christine Oughton and Alessandro Viviani for their comments on a previous version, as well as the anonymous referee. We would also like to thank Alberto Petrucci and the participants to the conference of the CNR group Economia Internazionale, held in Villa Mondragone (Roma, 17-18 September 2007). Giorgia Giovannetti and Giorgio Ricchiuti gratefully acknowledge financial 
contributions from the FIRB project "International fragmentation of Italian firms. New organizational models and the role of information technologies". Margherita Velucchi gratefully acknowledges financial contributions from the research project no. 2005139545_003 funded by the MIUR. 


\section{References}

Agarwal R. (1997), "Survival of Firms over the Product Life Cycle", Southern Economic Journal, 3, pp.571-584

Agarwal R. (1998), "Evolutionary Trends of Industry Variables", International Journal of Industrial Organization, 16, pp. 511-526

Agarwal R, Gort M. (1996), "The Evolution of Markets and Entry, Exit and Survival of Firms", Review of Economics and Statistics, 78, pp.489-498

Agarwal R., Audretsch D. B. (2001), "Does entry size matter? The impact of the life cycle and technology on firm survival", The Journal of Industrial Economics, 1, pp. 21-43

Audretsch D.B. (1991),"New Firm Survival and the Technological Regime", Review of Economics and Statistics, 73, pp.441-450

Audretsch D.B. (1995), Innovation and Industry Evolution, Cambridge, MIT Press

Bartelsman E., Scarpetta S., Schivardi F. (2003),"Comparative Analysis of Firm Demographics and Survival: Micro-Level Evidence for the OECD Countries", OECD Economics Department Working Papers, No. 348, OECD

Bartelsman E., Haltiwanger J., Scarpetta S. (2004), "Microeconomic Evidence of Creative Destruction in Industrial and Developing countries", Tinbergen Institute Discussion Papers, TI 2004-114/3

Capitalia (2003), VIII Indagine sulle Imprese italiane, Osservatorio sulle piccole e medie imprese

Capitalia (2005), IX Indagine sulle Imprese italiane, Osservatorio sulle piccole e medie imprese 
Caves R., Porter M.E. (1977), "From Entry Barriers to Mobility Barriers", Quarterly Journal of Economics, 91, pp.241-261

Caves R. E. (1998), Industrial Organization and New Findings on the Turnover and Mobility of Firms, Journal of Economic Literature, Vol. 36, No. 4, pp. $1947-1982$

Clerides, S., Lach,S, Tybout, J. (1998), Is learning by exporting important? Micro-dynamic evidence from Columbia, Mexico and Morocco, Quarterly Journal of Economics, Vol. 113, pp.903-948

De Benedictis L., Giovannetti G. (2008) "Caratteristiche dell'Internazionalizzazione delle imprese in Italia. Esportazioni, Delocalizzazione ed Investimenti Diretti all'estero" Rapporto CER-ICE, Rubettino Editore, forthcoming

Dunne T., Roberts, M.J., Samuelson L. (1988), "Patterns of Firm Entry and Exit in the U.S. Manufacturing Industries", Rand Journal of Economics, 19, pp.495-515

Dunne T., Roberts, M.J., Samuelson L. (1989), "The Growth and the Failure of U.S. Manufacturing Plants", Quarterly Journal of Economics, 104, pp.671698

Eurostat (2006), European business - Facts and Figures

Evans D. (1987), "The Relationship between Firms Growth, Size and Age: Estimates from 100 Manufacturing Industries", Journal of Industrial Economics, 35, pp.567-581

Geweke, J, Marshall, R.C., Zarkin, G.A. (1986), "Mobility Indices in Continuous Time Markov Chains", Econometrica, 54(6), pp.1407-1423 
Geroski P.A. (1995), "What do we know about entry?" International Journal of Industrial Organization, 13, pp. 450-456

Gibrat R. (1931), Les Inégalités Économiques. Applications : Aux Inégalités des Richesses, à la Concentration des Entreprises, Aux Population des Villes, Aux Statistiques des Familles, etc., d'une Loi Nouvelle: La Loi de I'Effet Proportionnel, Paris, Librairie du Recueil Sirey

Hall B.(1987), "The Relationship Between Firm Size and Firm Growth in the U.S. Manufacturing Sector", Journal of Industrial Economics, 35, pp.583-606 Holmes, P., Hunt, A. and Stone, I. (2008) "An analysis of new firm survival using a hazard function", Applied Economics, 99999:1

ISTAT (2005), Rapporto Annuale, Roma

Lisbon European Council (2000),

http://www.europa.eu.int/comm/lisbon strategy/index en.html.

Klein J.P. and Moeschberger M.L., (2003), Survival Analysis: Techniques for censored and truncated data, 2nd ed., New York, Springer

Jovanovic, B. (1982), "Selection and the Evolution of Industry", Econometrica, Econometric Society, vol. 50(3), pp. 649-670

Lancaster, T. (1990), The Analysis of Transition Data, New York: Cambridge University Press

Leung, M. K., Rigby, D. and Young, T. (2003) "Entry of foreign banks in the People's Republic of China: a survival analysis"; Applied Economics,35:1,2131

Mansfield, E. (1962), "Entry, Gibrat's Law, Innovation, and the Growth of Firms", American Economic Review, 52, pp. 1023-1051 
Mariotti S., Mutinelli M. (2005), Italia Multinazionale 2004. Le partecipazioni Italiane all'estero e estere in Italia, Soveria Mannelli, Rubbettino Editore.

Mata J., Portugal P. (1994), "Life Duration of New Firms", Journal of Industrial Economics, 27, pp.227-246

Mayer, T., Ottaviano, G.M. (2007), The Happy Few the internationalization of European Firms, Bruegel blueprint series, n. 3

Melitz, M. (2003), "The Impact of Trade on Intra-Industry Reallocations and Aggregate Industry Productivity" Econometrica, Econometric Society, vol. 71(6), pp. $1695-1725$

Melitz, M, Ottaviano G. M. (2008), "Market Size, Trade, and Productivity", Review of Economic Studies, Vol. 75, Issue 1, pp. 295 - 316

Porter M.E. (1979), "The structure within industries and companies performance", Review of Economics and Statistics, 61, pp. 214-227

Santarelli, E. (1998), "Start-up size and post-entry performance: the case of tourism services in Italy", Applied Economics, 30:2, 157-163

Santarelli E., Klomp L., Turik R. (2006), "Gibrat Law: an Overview of the Empirical Literature", in Santarelli (eds.), Entrepreneurship, Growth, and Innovation: the Dynamics of Firms and Industries, Springer, New York

Steindl J. (1965), Random Processes and the Growth of the Firms: A Study of the Pareto Law, London: Griffith

Sutton J. (1997), "Gibrat's Legacy", Journal of Economic Literature, 35, pp. 40-59.

Sutton J. (1998), Technology and market structure: Theory and History, Cambridge, Mass, the MIT Press. 
Table 1 - Descriptive Statistics (average and standard errors of the sample, 2001-2005)

\begin{tabular}{|c|c|c|c|c|c|c|c|}
\hline Variables & Exporter & Non-Exporter & Small & Medium - Large & Innovative & $\begin{array}{c}\text { Non - } \\
\text { Innovative }\end{array}$ & Whole Sample \\
\hline \multirow[t]{2}{*}{ Size } & 3.199 & 2.393 & 1 & 3.497 & 3.128 & 2.775 & 2.994 \\
\hline & (1.384) & $(1.328)$ & (0) & (1.117) & $(1.391)$ & (1.424) & (1.414) \\
\hline \multirow{2}{*}{$\begin{array}{l}\text { Age of the Firm } \\
\text { (Span) }\end{array}$} & 24.955 & 24.265 & 22.526 & 25.348 & 24.809 & 24.731 & 24.78 \\
\hline & (15.947) & (14.885) & (13.384) & (16.167) & (15.246) & $(16.381)$ & (15.687) \\
\hline \multirow[t]{2}{*}{ Technology } & 0.357 & 0.182 & 0.294 & 0.317 & 0.354 & 0.245 & 0.313 \\
\hline & $(0.479)$ & $(0.386)$ & $(0.456)$ & $(0.465)$ & $(0.478)$ & $(0.43)$ & $(0.464)$ \\
\hline \multirow[t]{2}{*}{ Innovation } & 0.671 & 0.471 & 0.528 & 0.643 & 1 & 0 & 0.62 \\
\hline & $(0.47)$ & $(0.499)$ & $(0.499)$ & $(0.479)$ & (0) & (0) & $(0.485)$ \\
\hline \multirow[t]{2}{*}{ Export } & 1 & 0 & 0.579 & 0.788 & 0.807 & 0.647 & 0.746 \\
\hline & $(0)$ & $(0)$ & $(0.494)$ & $(0.409)$ & $(0.395)$ & $(0.478)$ & $(0.435)$ \\
\hline \multirow[t]{2}{*}{ FDI } & 0.132 & 0.026 & 0.037 & 0.123 & 0.12 & 0.081 & 0.105 \\
\hline & $(0.339)$ & $(0.16)$ & $(0.189)$ & $(0.328)$ & $(0.325)$ & $(0.273)$ & $(0.307)$ \\
\hline \multirow[t]{2}{*}{$R \& D$} & 0.528 & 0.213 & 0.318 & 0.481 & 0.622 & 0.163 & 0.448 \\
\hline & (0.499) & $(0.41)$ & $(0.466)$ & $(0.5)$ & $(0.485)$ & $(0.37)$ & $(0.497)$ \\
\hline Observations & 15710 & 5345 & 4241 & 16814 & 13055 & 8000 & 21055 \\
\hline
\end{tabular}


Table 2 - Cox-Regressions

\begin{tabular}{|c|c|c|c|c|c|c|c|c|c|}
\hline & 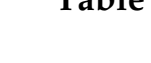 & $\begin{array}{l}\text { ox-Kegress } 1 \\
\text { Whole Sample }\end{array}$ & & Exporter & Non - Exporter & Small & Medium - Large & Innovative & Non - Innovative \\
\hline \multirow{3}{*}{ Size } & Baseline & $\begin{array}{c}\text { Baseline + } \\
\text { Innovation }\end{array}$ & General Model & & & & & & \\
\hline & 0.802 & 0.784 & 0.756 & 0.77 & 0.836 & & & 0.807 & 0.786 \\
\hline & {$[0.023]^{* * *}$} & {$[0.023]^{* * *}$} & {$[0.024]^{* * *}$} & {$[0.025]^{* * *}$} & {$[0.057]^{* * *}$} & & & {$[0.030]^{* * *}$} & {$[0.037]^{* * *}$} \\
\hline \multirow[t]{2}{*}{ Technology } & 0.745 & 0.684 & 0.652 & 0.668 & 0.98 & 0.805 & 0.693 & 0.578 & 1.15 \\
\hline & {$[0.0608]^{* * *}$} & {$[0.057]^{* * *}$} & {$[0.055]^{* * *}$} & {$[0.060]^{* * *}$} & [0.195] & {$[0.105]^{*}$} & {$[0.073]^{* * *}$} & {$[0.061]^{* * *}$} & {$[0.148]$} \\
\hline \multirow[t]{2}{*}{ Innovation } & & 0.912 & 0.898 & & & & & & \\
\hline & & [0.071] & [0.069] & & & & & & \\
\hline \multirow[t]{2}{*}{ Export } & & & 1.32 & & & & & & \\
\hline & & & {$[0.116]^{* * *}$} & & & & & & \\
\hline \multirow[t]{2}{*}{ FDI } & & & 1.38 & & & & & & \\
\hline & & & {$[0.160]^{* * *}$} & & & & & & \\
\hline \multirow[t]{2}{*}{$R \& D$} & & 1.537 & 1.448 & & & & & & \\
\hline & & {$[0.117]^{* * *}$} & {$[0.112]^{* * *}$} & & & & & & \\
\hline Observations & 21055 & 21055 & 21055 & 15710 & 5345 & 4241 & 16814 & 13055 & 8000 \\
\hline Exits & 832 & 832 & 832 & 645 & 187 & 317 & 515 & 517 & 315 \\
\hline Log Likelihood & -7589.76 & -7574.39 & -7564.68 & -5666.549 & -1469.31 & -2345.577 & -4627.032 & -4431.377 & -2596.965 \\
\hline \multirow{2}{*}{$\begin{array}{c}\text { Chi-square } \\
\text { p-value }\end{array}$} & 76.24 & 105.45 & 117.75 & 83.33 & 7.14 & 2.79 & 12.24 & 64.01 & 26.42 \\
\hline & $(0.000)$ & $(0.000)$ & $(0.000)$ & $(0.000)$ & $(0.028)$ & $(0.095)$ & $(0.001)$ & $(0.000)$ & $(0.000)$ \\
\hline
\end{tabular}

Robust Standard Errors in brackets

${ }^{*}$ significant at $10 \%$; ${ }^{* *}$ significant at $5 \%$; ${ }^{* * *}$ significant at $1 \%$ 
Table 3 - Homogeneity tests: test of equality of survival functions

\begin{tabular}{c|cccc}
\hline & $\begin{array}{c}\text { Whole Sample vs. } \\
\text { Baseline }\end{array}$ & Exporter vs. Non-exporter & Small vs. Medium-Large & Innovative vs. Non-Innovative \\
Wilcoxson & 635.61 & 22.12 & 30.02 & 42.23 \\
p-value & $(0.000)$ & $(0.008$ & $(0.000)$ & $(0.000)$ \\
Log-Rank & 941.57 & 45.31 & 29.88 & 89.41 \\
p-value & $(0.000)$ & $(0.000)$ & $(0.000)$ & $(0.000)$ \\
Peto-Peto Prentice & 922.32 & 44.13 & 30.01 & 86.71 \\
p-value & $(0.000)$ & $(0.000)$ & $(0.000)$ & $(0.000)$ \\
Tarone Ware & 747.91 & 31.12 & 29.01 & 59.22 \\
p-value & $(0.000)$ & $(0.000)$ & $(0.000)$ & $(0.000)$ \\
Note: Null hypothesis is that groups survival functions are equal. The difference among the tests is related to the weight at each distinct failure time ti.
\end{tabular}

See Klein and Moeschberger, 2003 


\section{Figure 1 Hazard Function Whole Sample}

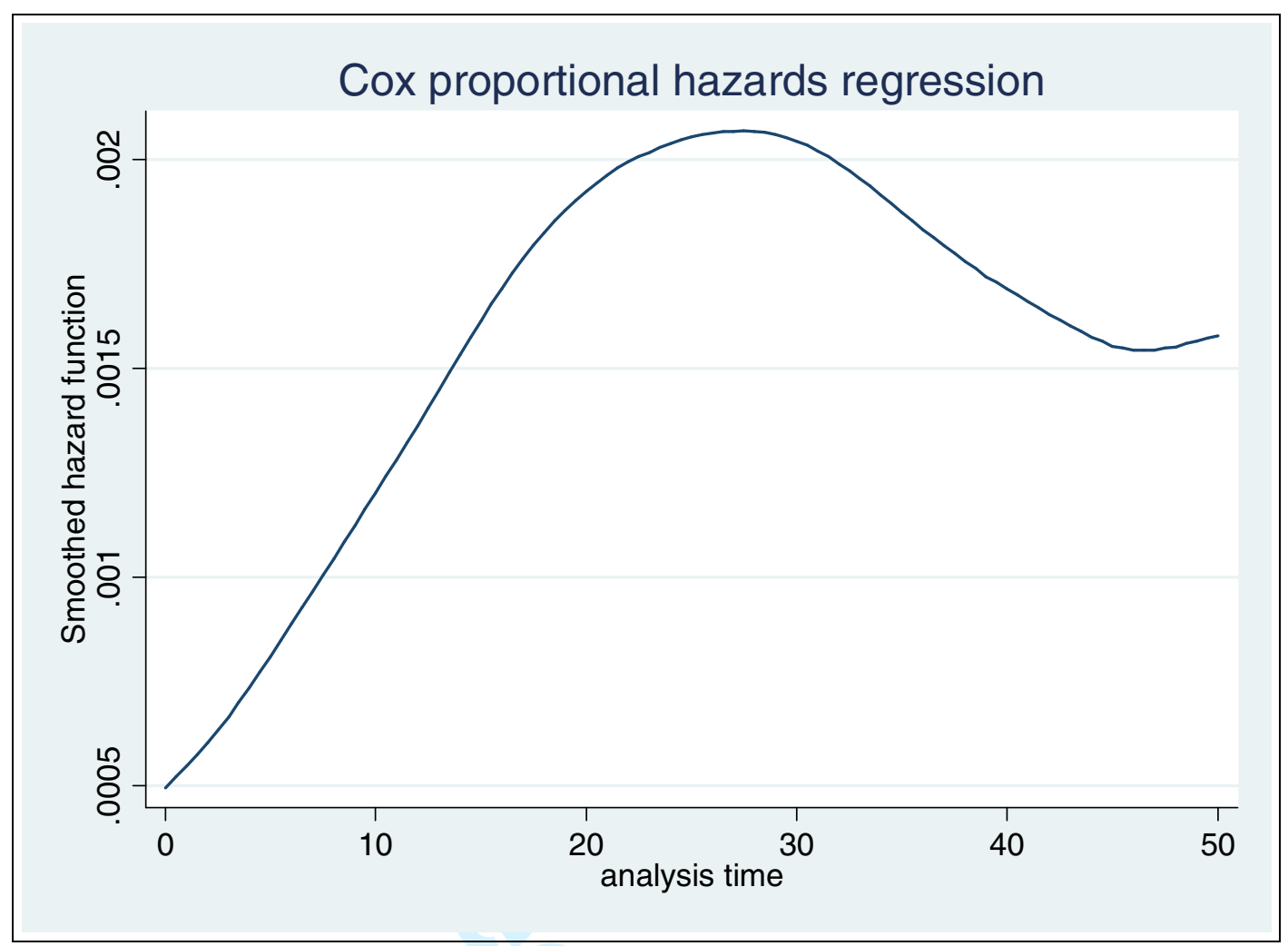

Figure 2 Hazard Functions for smallest and biggest firms

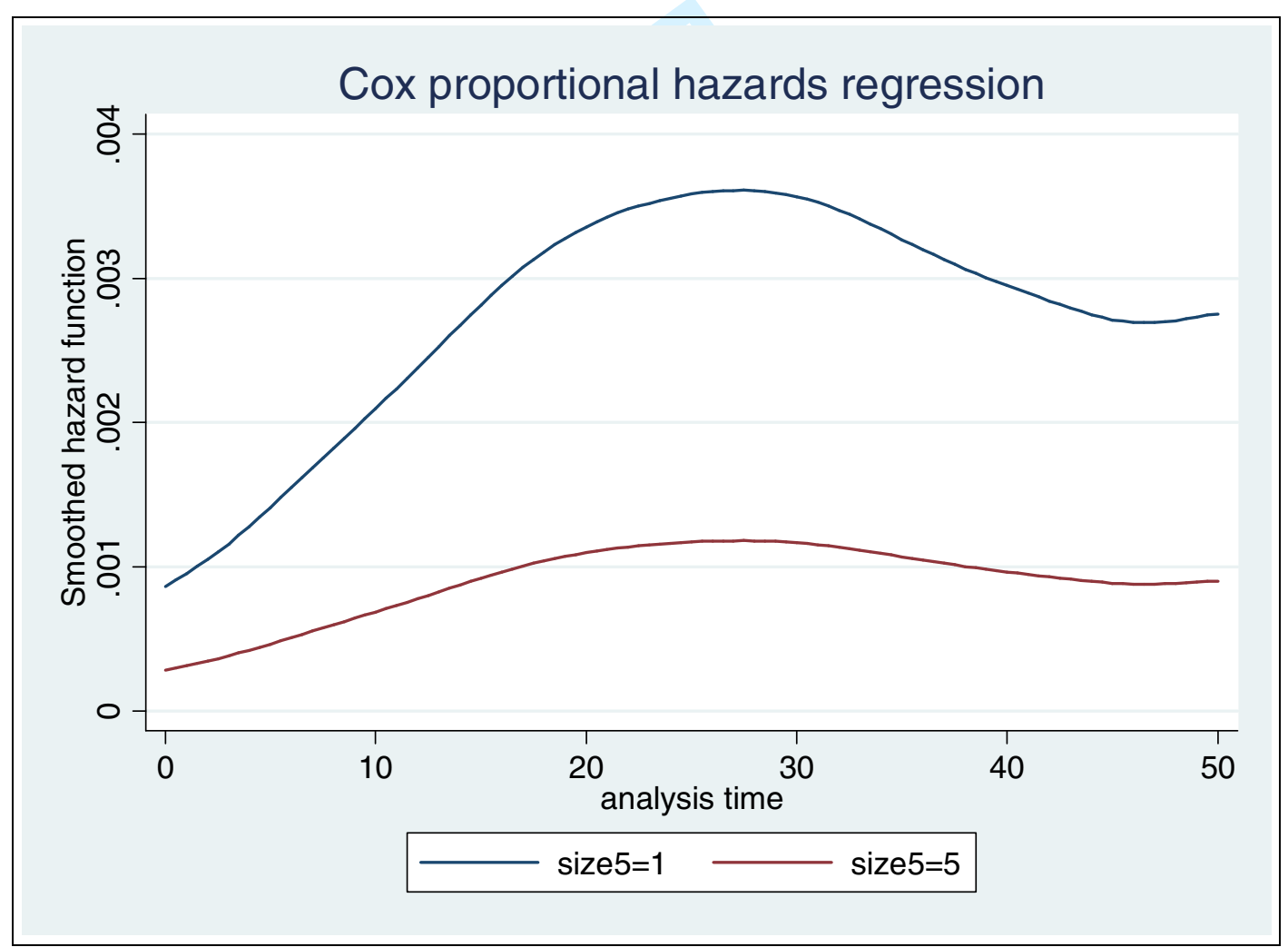




\section{Figure 3 Hazard Function for Low and High Tech Firms}

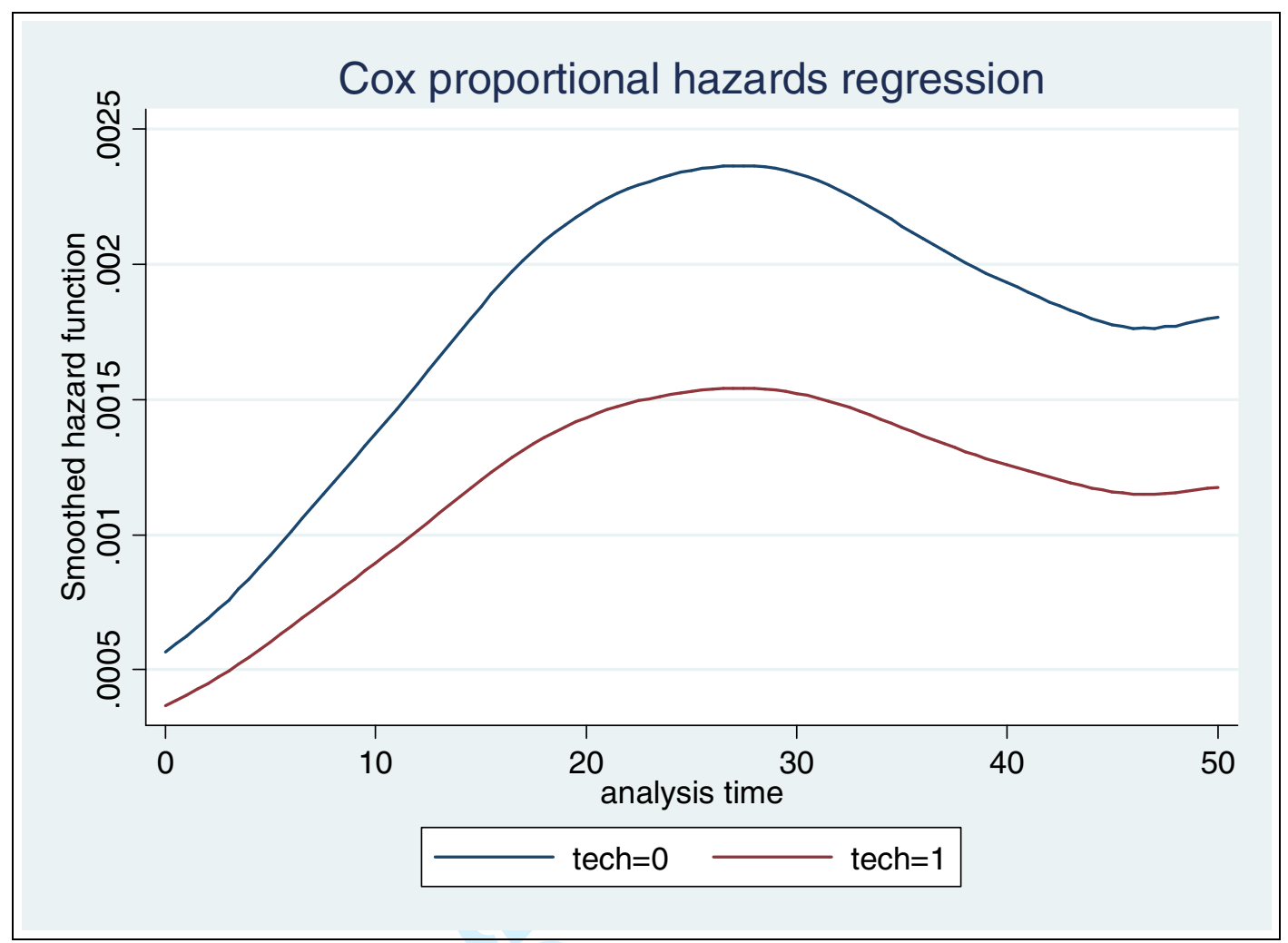

\section{Figure 4 Hazard Function for FDI and Non-FDI Makers}

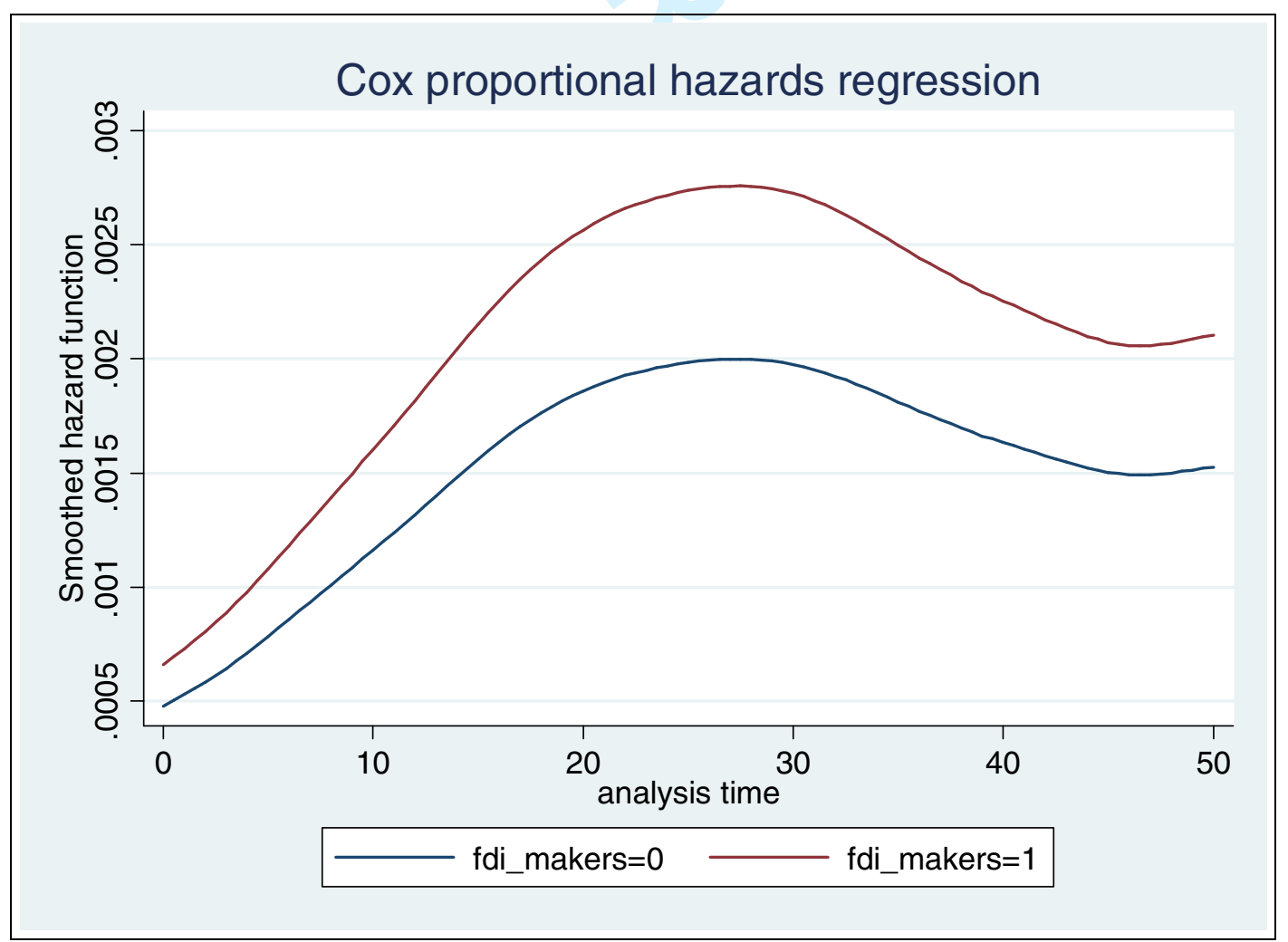


Figure 5 Hazard Function for Exporting and Non-Exporting Firms

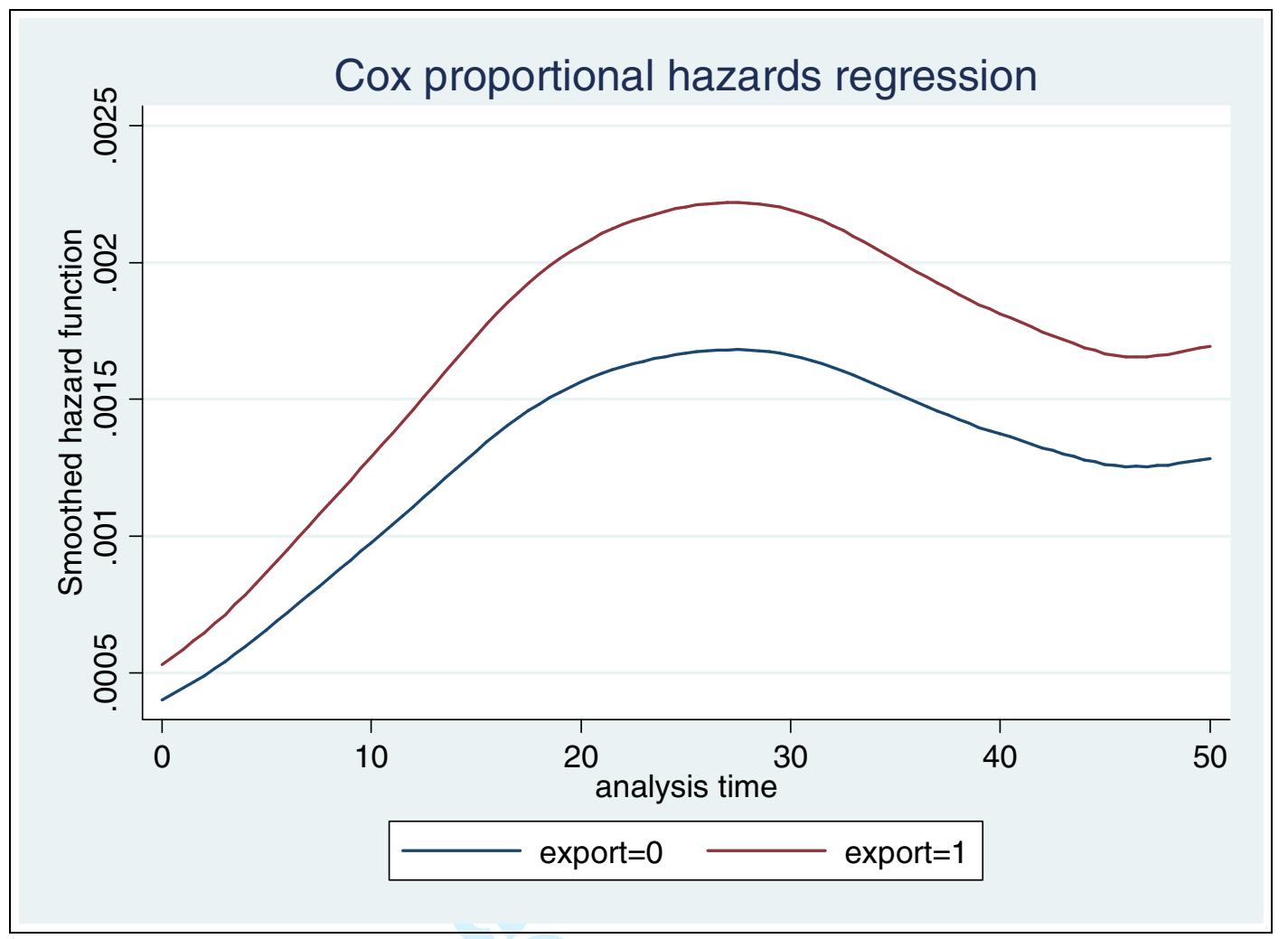

Figure 6 Hazard Function for Innovative and Non-Innovative Firms

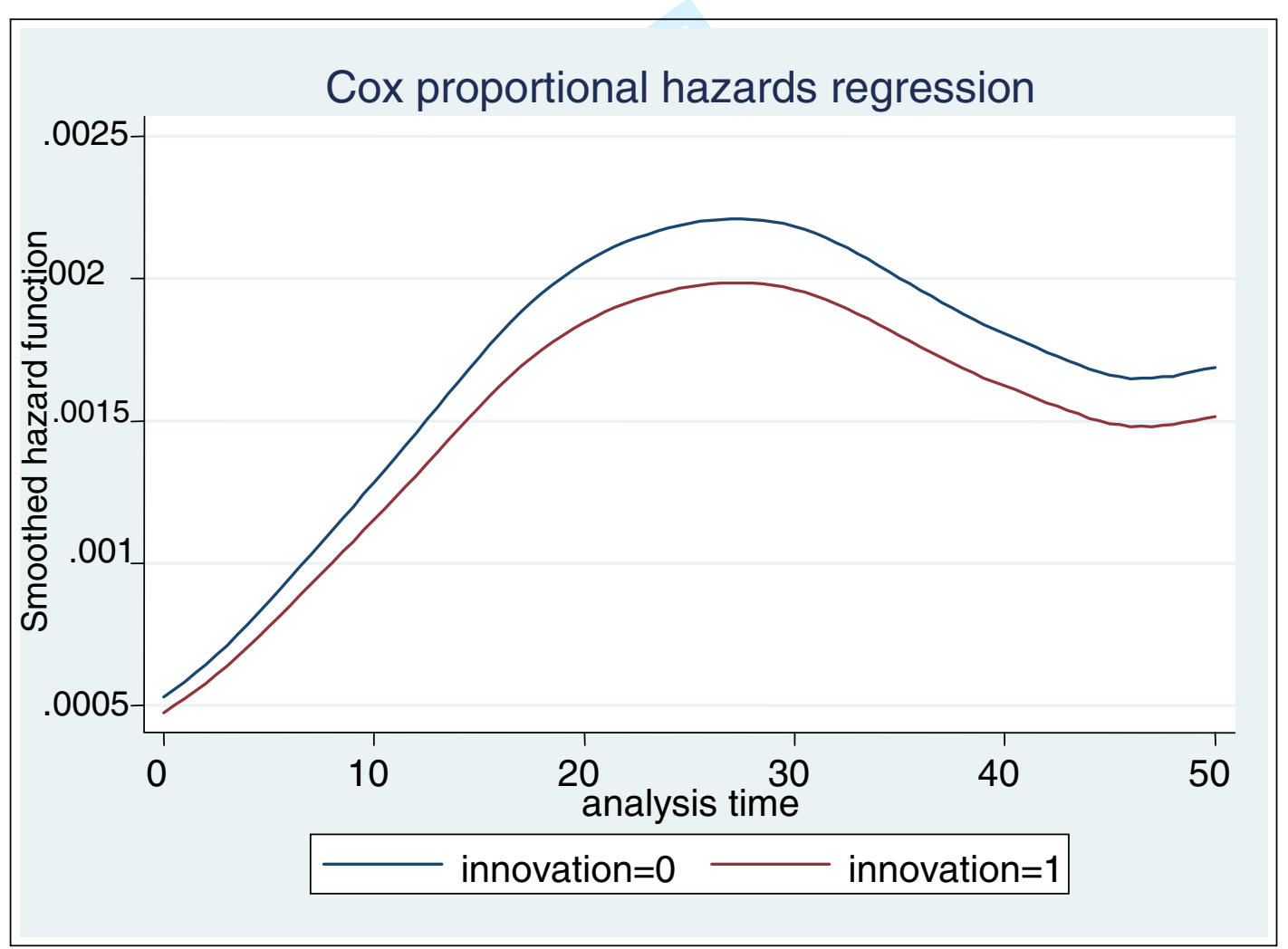

